\title{
Small bowel obstruction secondary to a Foley catheter perforating the bladder: a case report
}

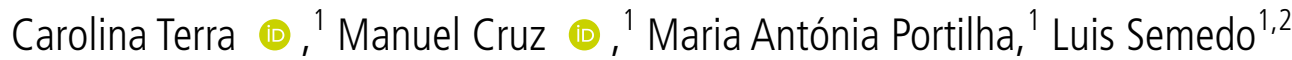

${ }^{1}$ Radiology, Centro Hospitalar e Universitario de Coimbra EPE, Coimbra, Portugal ${ }^{2}$ Faculdade de Medicina da Universidade de Coimbra, Coimbra, Portugal

\section{Correspondence to} Dr Carolina Terra; carolinaterrarodrigues@gmail. com

Accepted 26 March 2021

\section{DESCRIPTION}

An 87-year-old male patient, totally dependent on activities of daily living, was admitted to the emergency department with symptoms of anorexia, abdominal pain and faecaloid vomiting. His clinical history included benign prostatic hypertrophy, for which he had a long-term indwelling urinary (Foley) catheter that was changed every 3 months by a nurse in the facility where he lived, for the past 5 years.

The abdominal radiograph done at admission revealed marked gastric distension and multiple predominantly central dilated loops with air-fluid levels (figure 1). An abdominal CT was performed for further characterisation of these findings, disclosing small bowel obstruction (SBO) and perforation of the bladder wall by a Foley catheter. The transition point was located in the pelvic region, at the site of the perforation (video 1).

The patient underwent emergency laparotomy, which confirmed an inflammatory adhesion around the tip of the catheter, that had perforated the bladder wall through a diverticulum. Lysis of the adhesion and repair of the bladder wall were performed, without intraoperative complications. The patient experienced an uneventful postoperative recovery and died 1 year later from an unrelated cause.

SBO is a common clinical condition that accounts for $80 \%$ of all cases of mechanical intestinal obstruction, ${ }^{1}$ corresponding to $4 \%$ of emergency department admissions and 20\% of emergency surgical procedures in patients with abdominal pain. ${ }^{2}$

The aetiology of SBO is vast and has shifted over the past five decades, in the developed countries, from hernia to adhesions, Crohn disease and neoplasia as the top three causes. ${ }^{1}$

Imaging has become the primary focus in the diagnostic work-up of these patients, as it allows

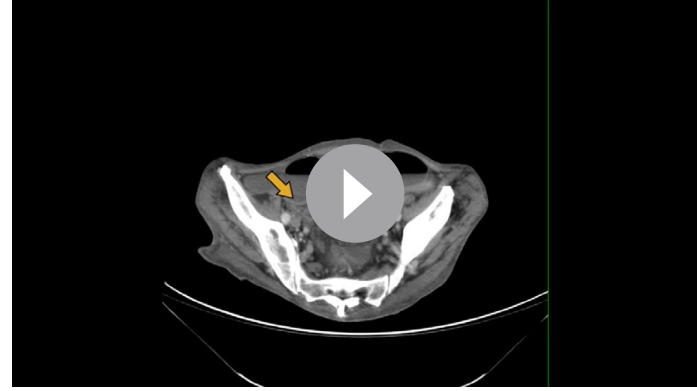

Video 1 On axial acquisition, the beak sign is found at the site of the Foley's extremity, in the right iliac fossa, indicating the transition point

preoperative confirmation of the obstruction, determination of its location and possible causes and assessment of severity and complications, namely strangulation or perforation. ${ }^{1}$

Since their introduction in 1929, Foley catheters are indispensable in modern clinical practice and are invariably used in patients who require an indwelling urinary catheter. ${ }^{3}$

Bladder diverticula consist of herniations of the urothelium through the muscularis propria of the bladder wall. They are outpouchings lined by a thin layer of serosa and adventitia and represent a significant point of weakness that predisposes to wall perforation. ${ }^{4}$ Chronic urinary stasis and inflammation in the diverticula, as well as increased bladder pressure, also increase the risk of rupture. ${ }^{5}$ We believe that the combination of the above factors may explain why the Foley catheter perforated the bladder wall in this case.

There are some reports of SBO secondary to suprapubic urinary catheters. ${ }^{5}$ However, to the best of our knowledge, this report represents the
Check for updates

(C) BMJ Publishing Group Limited 2021. No commercial re-use. See rights and permissions. Published by BMJ.

To cite: Terra C, Cruz M Portilha MA, et al. BMJ Case Rep 2021;14:e241076 doi:10.1136/bcr-2020 241076

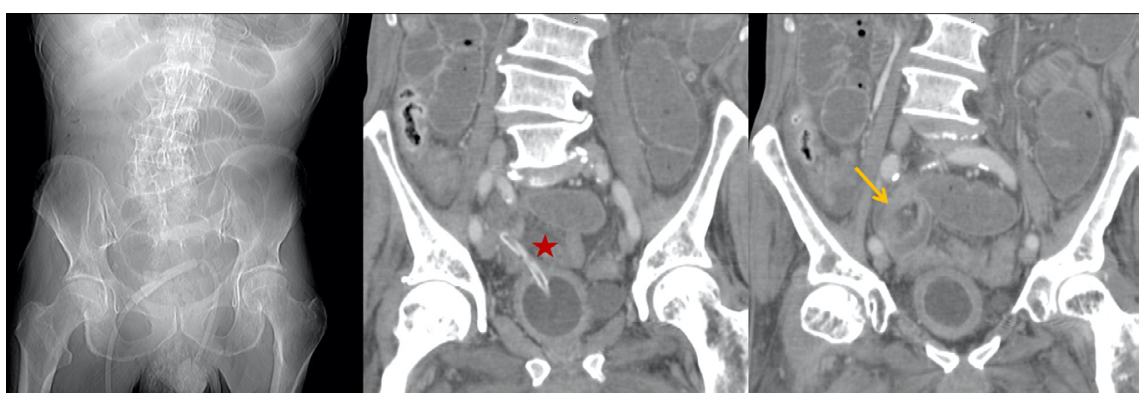

Figure 1 Abdominal CT scout view (left) with small bowel dilation. Coronal CT images show bladder wall perforation by a Foley catheter (star) and a twist swirl sign near the extremity of the Foley, indicating a possible transition point nearby (arrow). 


\section{Learning points}

- Foley catheters are indispensable in modern clinical practice and, although rarely, can complicate with bladder rupture.

- Urinary catheterisation must be performed carefully and the physician must understand the potential complications associated with catheter placement with timely diagnosis and treatment.

- CT is the best imaging modality to assess small bowel obstruction, both by confirming it and allowing determination of its location and aetiology.

second case described in the literature of a SBO caused by a longterm indwelling Foley catheter. ${ }^{7}$

Contributors CT wrote the manuscript. MC provided the videos. MAP provided the clinical data. LS reviewed the manuscript and gave the final suggestions.

Funding The authors have not declared a specific grant for this research from any funding agency in the public, commercial or not-for-profit sectors.
Competing interests None declared.

Patient consent for publication Obtained.

Provenance and peer review Not commissioned; externally peer reviewed.

\section{ORCID iDs}

Carolina Terra http://orcid.org/0000-0003-0639-4066

Manuel Cruz http://orcid.org/0000-0002-2173-6485

\section{REFERENCES}

1 Silva AC, Pimenta M, Guimarães LS. Small bowel obstruction: what to look for. Radiographics 2009;29:423-39.

2 Geffroy Y, Boulay-Coletta I, Jullès M-C, et al. Increased unenhanced bowel-wall attenuation at multidetector $\mathrm{CT}$ is highly specific of ischemia complicating small-bowel obstruction. Radiology 2014;270:159-67.

3 Feneley RCL, Hopley IB, Wells PNT. Urinary catheters: history, current status, adverse events and research agenda. J Med Eng Technol 2015;39:459-70.

4 Diverticula. Diagnostic pathology: genitourinary. Elsevier, 2016: 478-81.

5 Bonasso PC, Lucke-Wold B, Khan U. Small bowel obstruction due to suprapubic catheter placement. Urol Case Rep 2016;7:72-3.

6 Adeyemo B, Makovitch S, Foo D. A peculiar complication of suprapubic catheterization: recurrent ureteral obstruction and hydronephrosis. J Spinal Cord Med 2013:36:166-9.

7 Sullivan LP, Davidson PG, Kloss DA, et al. Small-bowel obstruction caused by a longterm indwelling urinary catheter. Surgery 1990;107:228-30.

Copyright 2021 BMJ Publishing Group. All rights reserved. For permission to reuse any of this content visit https://www.bmi.com/company/products-services/rights-and-licensing/permissions/

BMJ Case Report Fellows may re-use this article for personal use and teaching without any further permission.

Become a Fellow of BMJ Case Reports today and you can:

- Submit as many cases as you like

- Enjoy fast sympathetic peer review and rapid publication of accepted articles

- Access all the published articles

- Re-use any of the published material for personal use and teaching without further permission

\section{Customer Service}

If you have any further queries about your subscription, please contact our customer services team on +44 (0) 2071111105 or via email at support@bmj.com.

Visit casereports.bmj.com for more articles like this and to become a Fellow 